\title{
Inhibition Effect of Some Inhibitors on Super 13Cr Steel Corrosion in Completion Fluid
}

\author{
Li Lingjie ${ }^{1,2, ~ *, ~ Y a n g ~ Y a o h u i ~}{ }^{1,2}$, Zhou Bing ${ }^{1,2}$, Zhang Yanjun ${ }^{1,2}$, Lin Zhu ${ }^{1,2}$, Tong Hui ${ }^{1,2}$ \\ ${ }^{1}$ CNPC Research Institute of Engineering Technology, Tianjin, China \\ ${ }^{2}$ Key Laboratory of Tubular Goods Engineering, CNPC-Research Division of Anti-Corrosion Coating and Thermal Insulation Structure, \\ Tianjin, China
}

\author{
Email address: \\ lilingj@cnpc.com.cn (Li Lingjie), yangyh.cpoe@cnpc.com.cn (Yang Yaohui) \\ ${ }^{*}$ Corresponding author
}

\section{To cite this article:}

Li Lingjie, Yang Yaohui, Zhou Bing, Zhang Yanjun, Lin Zhu, Tong Hui. Inhibition Effect of Some Inhibitors on Super 13Cr Steel Corrosion in Completion Fluid. American Journal of Chemical Engineering. Vol. 5, No. 4, 2017, pp. 74-80. doi: 10.11648/j.ajche.20170504.14

Received: May 27, 2017; Accepted: June 30, 2017; Published: July 19, 2017

\begin{abstract}
The inhibition effect of some inhibitors on super $13 \mathrm{Cr}$ stainless steel corrosion in $\mathrm{CaCl}_{2}$ completion fluids with $1.0 \mathrm{MPa} \mathrm{CO}_{2}$ was investigated. The results indicated that the super $13 \mathrm{Cr}$ stainless steel was susceptible to uniform and stress corrosion cracking (SCC) without inhibitors. After addition urotropine, the uniform corrosion was inhibited, and the SCC sensitivity of super $13 \mathrm{Cr}$ steel decreased. Electrochemical noise results indicated that the noise resistance increased obviously after addition urotropine.
\end{abstract}

Keywords: Stress Corrosion Cracking, Inhibitors, Completion Fluid, Electrochemical Noise

\section{Introduction}

Stress corrosion cracking (SCC) of stainless steels is produced by the simultaneous action or synergy of a mechanical tension and a corrosive medium, which is an electrochemical reaction between material and its environment [1-6], SCC is governed by the parameters such as stress, $\mathrm{pH}$, temperature and $\mathrm{CaCl}_{2}$ concentration etc [7-11]. Some kind of mechanisms for SCC has been reported [12-14], but at present, the mechanism of SCC has not been explained satisfied. Relatively poor measuring techniques are one of the main reasons for this lack of knowledge about SCC processes.

Adding inhibitor is an effective way to control SCC [15-17]. The synergistic effect of $\mathrm{CHN}$ with $\mathrm{MoO}$, can reduce the prestressed steel wire $\mathrm{SWRH} 77 \mathrm{~B}$ in $3.5 \% \mathrm{NaCl}+$ saturated solution stress corrosion sensitivity, prevent stress corrosion cracking effectively [18]. N. Cansever examined the inhibition effect of "chloride + molybdate" ions on the SCC of AISI 304 SS [19]. Isao Sekine investigated Corrosion inhibition of mild steel (JIS SS 41, UNS K02600) and stainless steel (type 304, UNS S30400) in hot $\mathrm{K}_{2} \mathrm{CO}_{3}$ solution [20].

In this paper, the inhibition effect on SCC and general corrosion of super $13 \mathrm{Cr}$ steel in $\mathrm{CaCl}_{2}$ completion fluid of some kind of inhibitors was investigated.

\section{Experimental}

\subsection{Materials and Solutions}

The test specimens were cut from super $13 \mathrm{Cr}$ stainless steel tube. The chemical component and mechanical property were shown in Table1, where $E_{\text {mod }}$ is the module for elasticity, $Y S$ is the stress corresponding to $0.6 \%$ strain, $t$ is the thickness of specimen, $H$ is the distance between outer support and $A$ is the distance between outer and inner support. The four-point-bend test specimens were prepared according to ISO7539-2: 1989(E) [21] and based on the ASTM-30 with dimension $80 \times 12 \times 2 \mathrm{~mm}$. The distance between outer support $(H)$ and the distance between outer and inner support $(A)$ are $60 \mathrm{~mm}$ and $15 \mathrm{~mm}$, respectively. The deflection between inner supports $(y)$ was controlled at $2.5 \mathrm{~mm}$, thus the stress of super $13 \mathrm{Cr}$ steel corresponding to $2.5 \mathrm{~mm}$ of deflection is calculated to be $1158 \mathrm{MPa}$ based on the following equation, which $\mathrm{t}$ is the specimen thickness.

$$
\sigma=\frac{12 \mathrm{Ety}}{3 \mathrm{H}^{2}-4 \mathrm{~A}^{2}}
$$


Table 1. Chemical component and mechanical performance of super $13 \mathrm{Cr}$ stainless steel.

\begin{tabular}{|c|c|c|c|c|c|c|c|c|c|}
\hline \multicolumn{10}{|c|}{ Chemical element $(w t \%)$} \\
\hline $\mathrm{C}$ & $\mathrm{Si}$ & $\mathrm{Mn}$ & $\mathrm{Cr}$ & $\mathrm{Ni}$ & Mo & $\mathrm{P}$ & S & $\mathrm{V}$ & $\mathrm{Ti}$ \\
\hline 0.01 & 0.23 & 0.42 & 12.0 & 5.4 & 1.9 & 0.014 & 0.001 & 0.06 & 0.09 \\
\hline \multicolumn{10}{|c|}{ Mechanical property } \\
\hline \multicolumn{2}{|c|}{ YSMPa } & \multicolumn{3}{|c|}{$\mathrm{TS}, \mathrm{MPa}$} & \multicolumn{2}{|c|}{ EL, \% } & \multicolumn{3}{|c|}{$E_{\text {mod }} \mathrm{GPa}$} \\
\hline \multicolumn{2}{|l|}{825} & \multicolumn{2}{|c|}{857} & & \multicolumn{2}{|c|}{26} & \multicolumn{3}{|c|}{191} \\
\hline
\end{tabular}

For electrochemical measurements under applied tensile stress condition, one end of the specimen was connected with an aviatic lead by welding and sealed with hydroxybenzene titanium lacquer, only leaving the tensile side between outer supports $\left(3.6 \mathrm{~cm}^{2}\right)$ exposed to test solutions.

The completion fluid was prepared by adding $39 \mathrm{wt} \% \mathrm{CaCl}_{2}$ brine, and deaerated by bubbling $\mathrm{N}_{2}$ gas for $12 \mathrm{~h}$ and bubbling $\mathrm{CO}_{2}$ for $6 \mathrm{~h}$. Then $0.2 \%$ acetic acid was added which was used as a blank solution. The inhibitor-containing solutions were prepared by adding inhibitors in the blank solution.

\subsection{Polarization Curves Measurements}

For the polarization curves measurements, the four-point-bend test specimen was placed in a conventional three-electrode electrolyte cell system and used as a working electrode. A platinum electrode and an $\mathrm{Ag} / \mathrm{AgCl}$ electrode were used as the reference electrodes, respectively. Polarization curves were obtained by sweeping the electrode potential from $-250 \mathrm{mV}$ to $+250 \mathrm{mV}$ versus the open circuit potential (OCP) at a scan rate of $0.3 \mathrm{mV} \mathrm{s}^{-1}$ after the working electrode reached a steady-state in the test solution. The test solutions were the completion fluids with and without inhibitors. After the test solutions and specimens placed in autoclave, $\mathrm{CO}_{2}$ was purged into the autoclave and partial pressure of $\mathrm{CO}_{2}$ was maintained at $1.0 \mathrm{MPa}$, the temperature was controlled at $125^{\circ} \mathrm{C}$.

\subsection{Electrochemical Noise Measurements}

For electrochemical noise (EN) measurements, a four-point-bend test specimen and an unloaded super $13 \mathrm{Cr}$ steel specimen with the dimension of $80 \mathrm{~mm} \times 2 \mathrm{~mm} \times 2 \mathrm{~mm}$ were used as working electrodes. Also an $\mathrm{Ag} / \mathrm{AgCl}$ electrode was used as the reference electrode. EN was measured in a freely corroding system (without an externally applied current or voltage). A home-made zero resistance ammeter (ZRA, current sensitivity $>10 \mathrm{pA}$, voltage sensitivity $>10 \mu \mathrm{V}$ ) measurement system with a sampling rate of $10 \mathrm{~Hz}$ was used to record the current and potential noise simultaneously, that is, the galvanic current flowing between two working electrodes and the potential difference between the coupled working electrodes and the reference electrode. The test solutions also were the completion fluids with and without inhibitors. And the $\mathrm{EN}$ was measured in autoclave at $125^{\circ} \mathrm{C}$ with $1.0 \mathrm{MPa} \mathrm{CO}_{2}$.

\subsection{Surface Observation}

After 14 days of immersion in solutions with and without inhibitors, the four-point-bend test specimens surface morphologies were observed using Phillips Quanta 200 SEM. The experiments were carried out three times, and were highly reproducible.

\section{Results and Discussion}

\subsection{Inhibition Effect on Super 13Cr Steel of Some Inhibitors}

The test solutions were the completion fluids with $1 \%$ inhibitors. The solution was purged into the autoclave and partial pressure of $\mathrm{CO}_{2}$ was maintained at $1.0 \mathrm{MPa}$, the temperature was controlled at $125^{\circ} \mathrm{C}$. The following nine different inhibitors were tested, including urotropine, tungstate, thiourea, imidazoline, molybdate, iodide, chromate, dodecylamine and propargyl alcohol (PA). Figure 1 showed the polarization curves of super $13 \mathrm{Cr}$ steel in the completion fluids with and without $1 \%(\mathrm{Wt})$ inhibitor.

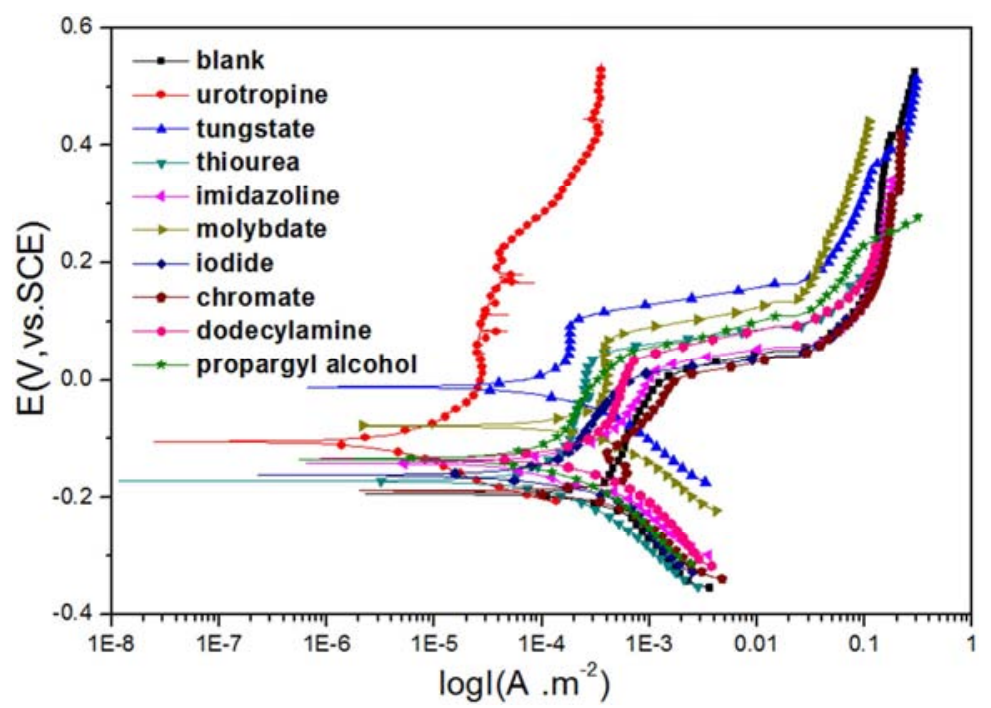

Figure 1. Polarization curves of super $13 \mathrm{Cr}$ steel in the completion fluids with and without $1 \%$ (Wt) inhibitor. 
Table 2. Fitting results of the polarization curves.

\begin{tabular}{llll}
\hline Inhibitors & $\boldsymbol{I}_{\text {corr }}\left(\boldsymbol{\mu} \mathbf{A} / \mathbf{c m}^{2}\right)$ & $\boldsymbol{E}_{\text {corr }}(\mathbf{m V})$ & $\boldsymbol{\eta}$ \\
\hline blank & 422.0 & -194 & - \\
$\mathrm{PA}$ & 81.6 & -135 & $80.66 \%$ \\
$\mathrm{KI}$ & 89.2 & -162 & $78.86 \%$ \\
$\mathrm{CrO}_{4}{ }^{2-}$ & 454.6 & -189 & - \\
Imidazoline & 105.3 & -141 & $75.05 \%$ \\
Dodecylamine & 147.5 & -134 & $65.05 \%$ \\
Thiourea & 90.7 & -171 & $78.51 \%$ \\
Urotropine & 5.5 & -105 & $98.70 \%$ \\
$\mathrm{MoO}_{4}{ }^{2-}$ & 221.3 & -78 & $47.56 \%$ \\
$\mathrm{WO}_{4}{ }^{2-}$ & 102.8 & -12 & $75.64 \%$ \\
\hline
\end{tabular}

The fitting results of Figure 1 were shown as Table 2. Which $I_{\text {corr }}$ is corrosion current, $E_{\text {corr }}$ is corrosion potential, and $\eta$ is Corrosion inhibition efficiency

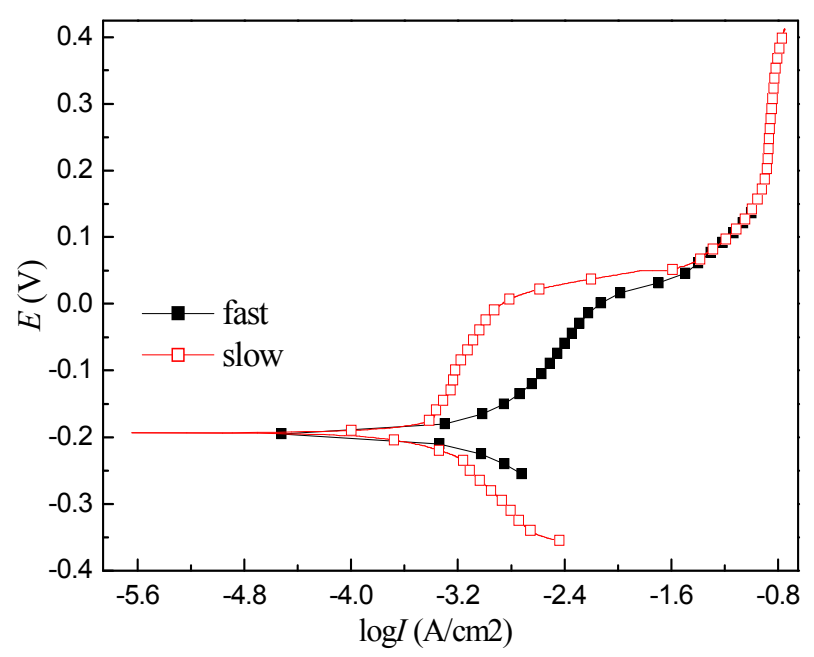

blank

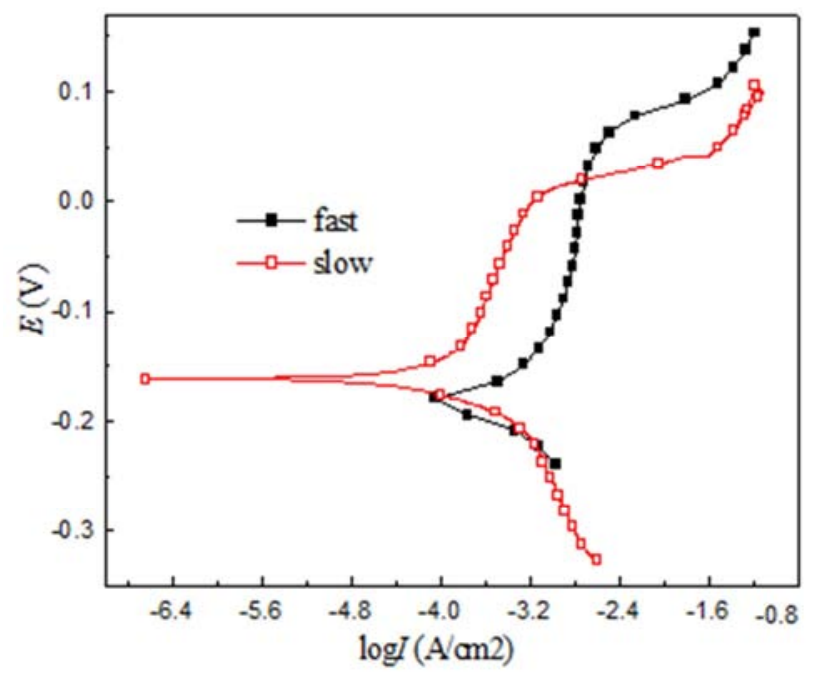

KI
The results indicated that urotropine had the best inhibition effect on uniform corrosion of super $13 \mathrm{Cr}$ steel in completion Fluid.

\subsection{Fast and Slow Scan Curves for Super 13Cr Steel}

The susceptive potential range can be found through fast and slow scan curves. The test solutions were $39 \mathrm{wt} \% \mathrm{CaCl}_{2}$ brine, The solution was deaerated by bubbling $\mathrm{N}_{2}$ gas for $12 \mathrm{~h}$ and bubbling $\mathrm{CO}_{2}$ for $6 \mathrm{~h}$, then 300ppm acetic acid and $1 \%$ inhibitor were added in, the temperature was controlled at $125^{\circ} \mathrm{C}$, the applied stress on super $13 \mathrm{Cr}$ steel was $100 \% \mathrm{YS}$. The fast scan rate was $0.3 \mathrm{mV} / \mathrm{s}$, and the slow one was $15 \mathrm{mV} / \mathrm{s}$. Figure 2 showed the fast and slow scan curves for super $13 \mathrm{Cr}$ steel.

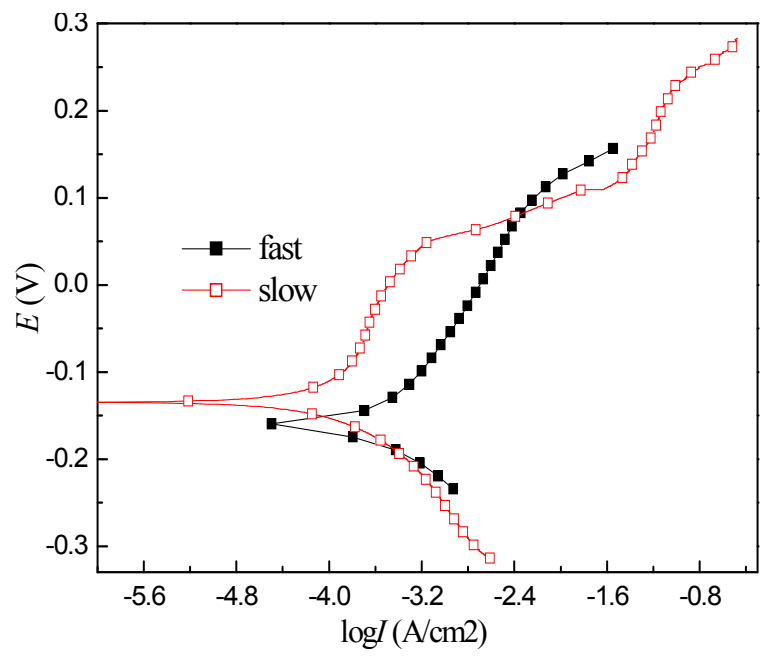

PA

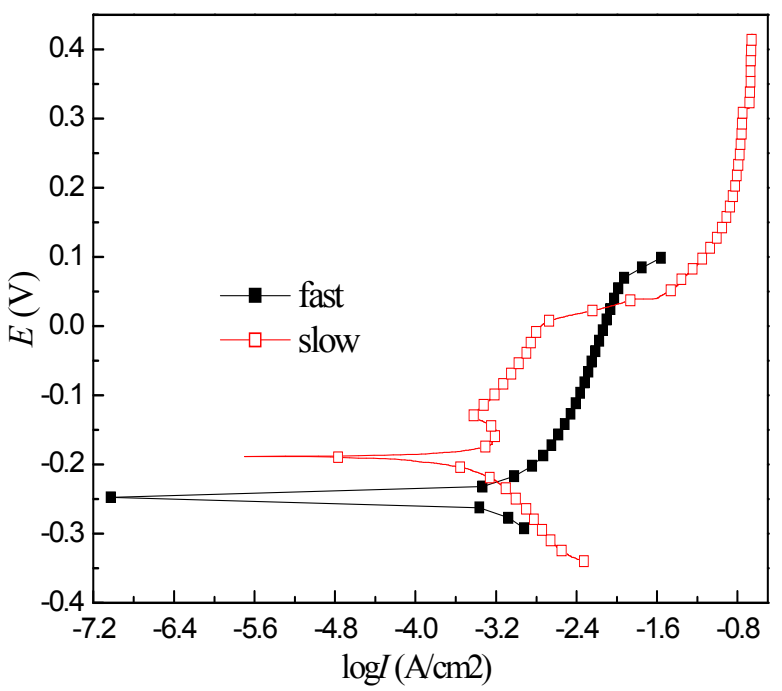

chromate 

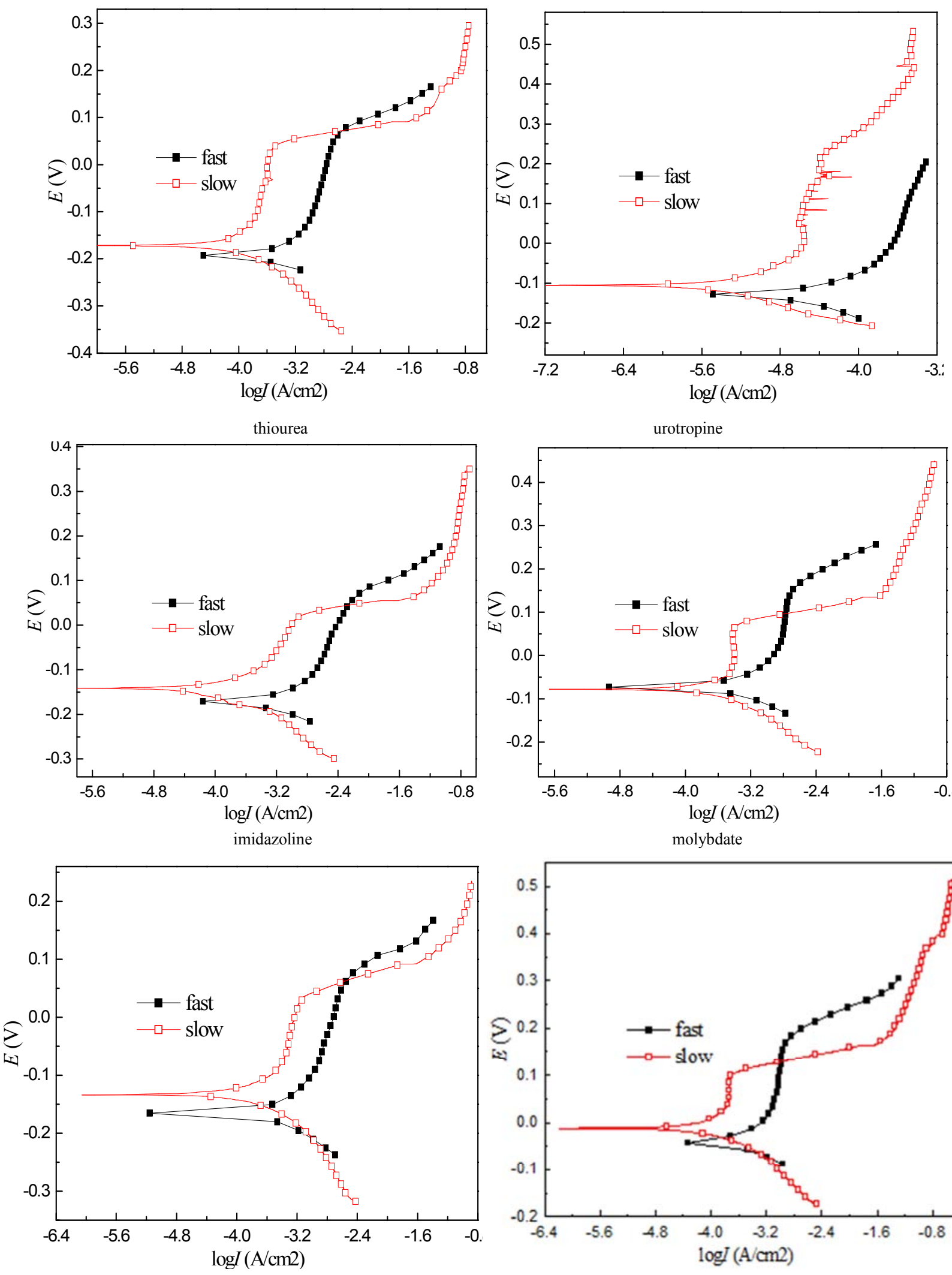

molybdate

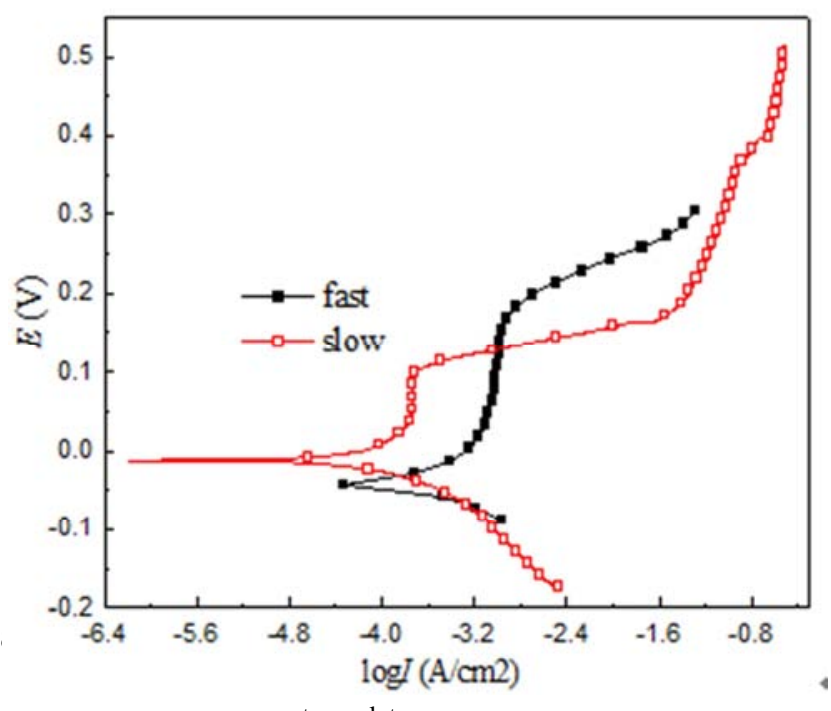

tungsdate

Figure 2. Fast and slow scan curves for super 13Cr steel.

The parameter Pi, which expressed the SCC susceptibility, can be calculated through the following equation based on the fast and slow scan curves. 


$$
\operatorname{Pi}=\left(i_{\mathrm{f}}\right)^{2} / \mathrm{i}_{\mathrm{s}}
$$

Where, $i_{f}$ is the fast scan current density, $i_{s}$ is the slow scan current density. The bigger is the Pi value, the more sensitivity to SCC the metal will be.

Figure 3 showed the Pi value of super $13 \mathrm{Cr}$ steel in $39 \% \mathrm{CaCl}_{2}$ solution with and without $1 \%$ inhibitor. Figure 3 indicated that after the addition of inhibitor, the SCC susceptibility of super $13 \mathrm{Cr}$ steel decreased.

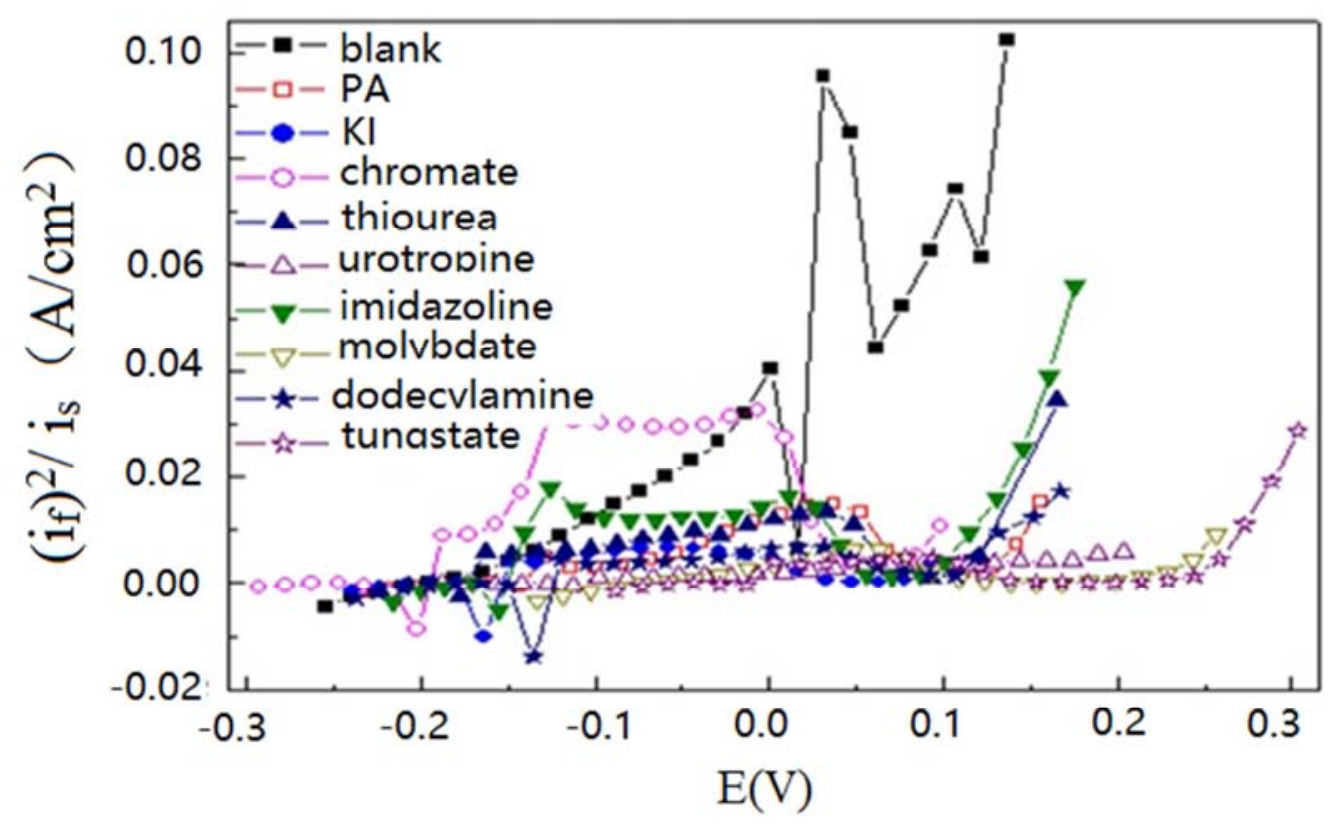

Figure 3. Pi value of super $13 \mathrm{Cr}$ steel in $39 \% \mathrm{CaCl}_{2}$ solution with and without $1 \%$ inhibitor.

\subsection{Electrochemical Noise Results on SCC of Super 13Cr Steel with and Without Inhibitor}

The test solution was $39 \mathrm{wt} \% \mathrm{CaCl}_{2}$ brine, the solution was deaerated by bubbling $\mathrm{N}_{2}$ gas for $12 \mathrm{~h}$ and bubbling $\mathrm{CO}_{2}$ for $6 \mathrm{~h}$, then $0.2 \%$ acetic acid and $1 \%$ inhibitor were added in. Finally, the solution was pumped in autoclave. $\mathrm{CO}_{2}$ was purged into the autoclave and partial pressure of $\mathrm{CO}_{2}$ was maintained at $1.0 \mathrm{MPa}$, the temperature was controlled at $125^{\circ} \mathrm{C}$, the applied stress on super $13 \mathrm{Cr}$ steel was $100 \%$ YS. Urotropine was selected as the inhibitor. Figure 4 showed the electrochemical noise of super $13 \mathrm{Cr}$ steel in the completion with and without $1 \%(\mathrm{Wt})$ inhibitor.

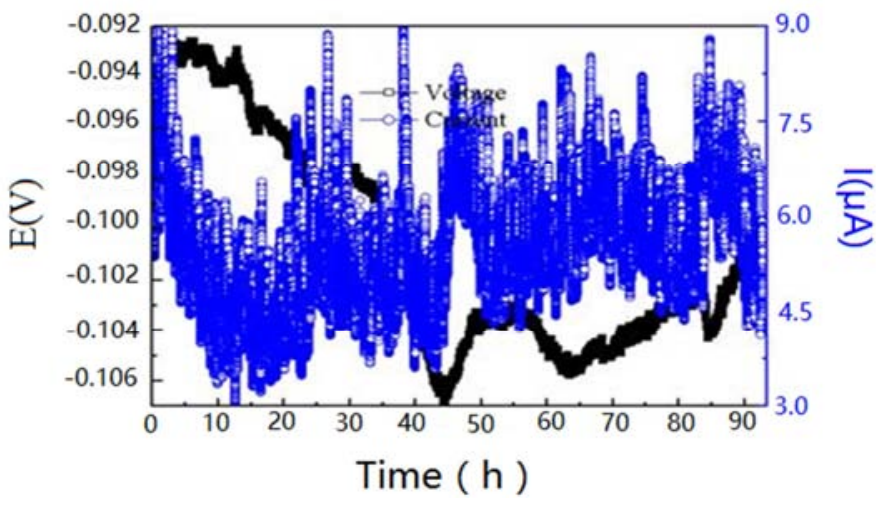

(a) blank

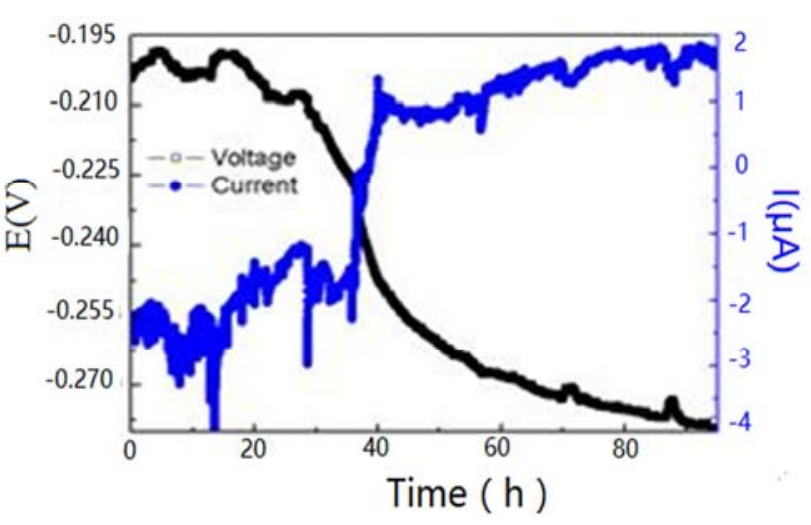

(b) with $1 \%(\mathrm{Wt})$ urotropine.

Figure 4. Electrochemical noise of super $13 \mathrm{Cr}$ steel in the completion with and without $1 \%$ (Wt) inhibitor a) blank; b) with $1 \%$ (Wt) urotropine.

Figure 4 indicated that the electrochemical noise was restrained after the addition of urotropine. The noise resistance $\left(R_{n}\right)$ was calculated based on the following equation: Where $S_{v}$ and $S_{I}$ are the votage and current standard deviation respectively.

$$
R_{n}=\frac{S_{v}}{S_{I}}
$$

The $S_{v}$ and $S_{I}$ were the votage and current standard deviation respectively. The $R_{n}$ of super $13 \mathrm{Cr}$ steel in blank solution was $1808 \Omega$ and the $R_{n}$ of super $13 \mathrm{Cr}$ steel in 
solution with $1 \%(\mathrm{Wt})$ urotropine was $18633 \Omega$, the $R_{n}$ increased obviously after the addition of urotropine, which indicated that the corrosion rate was decreased by urotropine.

\subsection{Effect of Urotropine on SCC of Super 13Cr Steel by Hang Sheet Experiment}

The test solutions were $39 \mathrm{wt} \% \mathrm{CaCl}_{2}$ brine with and

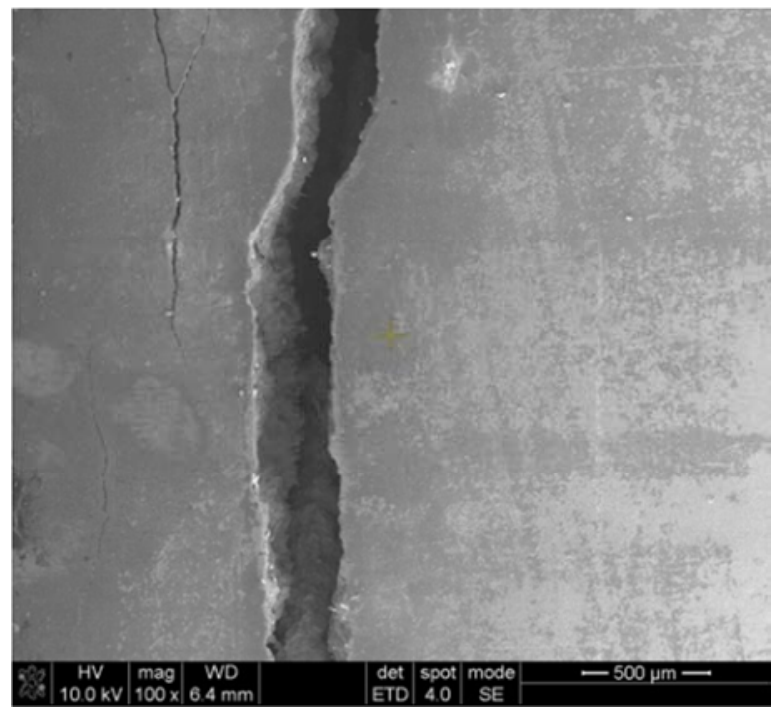

(a) blank without inhibitors, and the specimens were placed in PTFE vessel. The solution was deaerated by bubbling $\mathrm{N}_{2}$ gas for $12 \mathrm{~h}$ then bubbling $\mathrm{CO}_{2}$ for $6 \mathrm{~h}$ before PPET vessels placed in autoclave. $\mathrm{CO}_{2}$ was purged into the autoclave and partial pressure of $\mathrm{CO}_{2}$ was maintained at $1.0 \mathrm{MPa}$, the temperature was controlled at $125^{\circ} \mathrm{C}$. The test time was 14 days. The surface corrosion crack of four-point-bend experiment was invested, and the result was shown as the figure 5 .

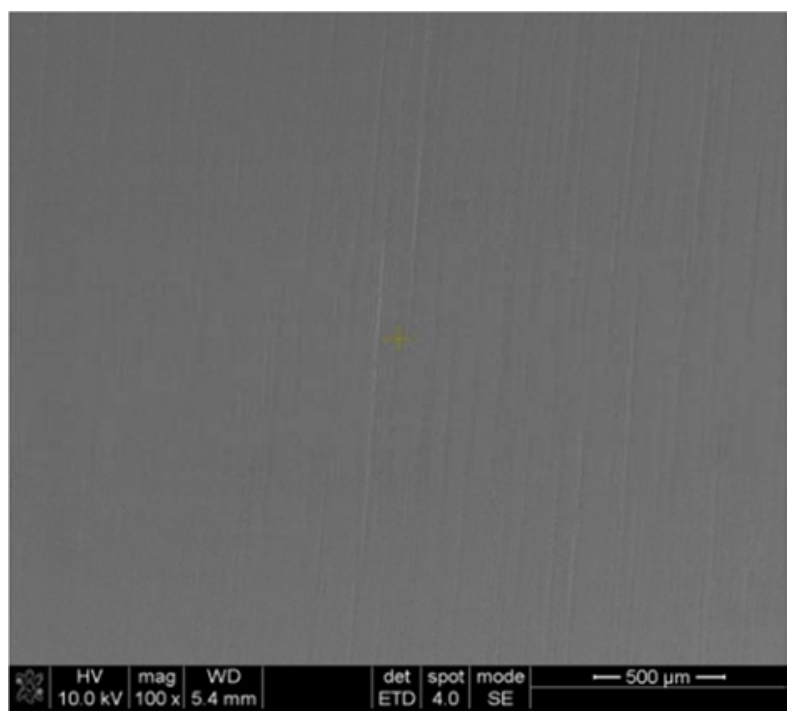

(b) with $1 \%(\mathrm{Wt})$ urotropine

Figure 5. Hanging results of super $13 \mathrm{Cr}$ steel in the completion with and without $1 \%(\mathrm{Wt})$ inhibitor a) blank; b) with $1 \%(\mathrm{Wt})$ urotropine.

The results indicated that the super $13 \mathrm{Cr}$ stainless steel was susceptible to stress corrosion cracking without adding inhibitor, which the four-point-bend test specimen was fractured and the surface of steel had some cracks. After addition urotropine, the SCC sensitivity of super $13 \mathrm{Cr}$ steel was decreased, and the surface of steel had none cracks. Urotropine could prevent the SCC of super $13 \mathrm{Cr}$ steel in the test condition.

\section{Conclusions}

At $1.0 \mathrm{MPa}, 125^{\circ} \mathrm{C}, \mathrm{SCC}$ of super $13 \mathrm{Cr}$ steel rapidly occurs in a $\mathrm{CO}_{2}$-saturated completionfluid in the presence of $0.2 \%$ acetic acid. Urotropine has good inhibition effect on general corrosion of super $13 \mathrm{Cr}$ steel in $\mathrm{CaCl}_{2}$ brine. And after adding $1 \%$ inhibitors, the SCC sensitivity of super $13 \mathrm{Cr}$ steel decreased. The hanging results show that the SCC of super $13 \mathrm{Cr}$ steel is inhibited after adding $1 \%$ urotropine.

\section{References}

[1] K Sieradzki, RC Newman. Stress corrosion cracking [J], Journal of Physics \& Chemistry of Solids, 2015, 48 (11):1101-1113.

[2] J. Landoulsi, K. Elkirat, C. Richard, D. Feron, S. Pulvin. Enzymatic Approach in Microbial-Influenced Corrosion: A Review Based on Stainless Steels in Natural Waters. Environ. Sci. Technol. 2008, 42, 2233-2242.
[3] J. Sanchez, J. Fullea, C. Andrade, C. Alonso, Stress corrosion cracking mechanism of prestressing steels in bicarbonate solutions. Corrosion Science, 2007 (49): 4069-4080.

[4] SK Manwatkar, SVS Narayana Murty, P Ramesh Narayanan. Stress Corrosion Cracking of High Strength $18 \mathrm{Ni}-8 \mathrm{Co}-5 \mathrm{Mo}$ Maraging Steel Fasteners [J], Materials Science Forum, 2015, 830-831: 717-720.

[5] XQ Dong, MR Li, YL Huang, LJ Feng. Effect of Potential on Stress Corrosion Cracking of 321 Stainless Steel under Marine Environment [J], Advanced Materials Research, 2015, 1090: 75-78.

[6] R Rihan, M Basha, A Al-Meshari, A Bayramov, GV Zyl. Stress Corrosion Cracking of SA-543 High-Strength Steel in All-Volatile Treatment Boiler Feed Water [J], Journal of Materials Engineering and Performance, 2015, 24 (10): $1-10$.

[7] Y Zhong, C Zhou, S Chen, R Wang. Effects of Temperature and Pressure on Stress Corrosion Cracking Behavior of $310 \mathrm{~S}$ Stainless Steel in Chloride Solution [J], Chinese Journal of Mechanical Engineering, 2017, 30 (1) :200-206.

[8] LW Cao, CY Du, GS Xie. Effects of Sensitization and Hydrogen on Stress Corrosion Cracking of 18-8 Type Stainless Steel [J], Applied Mechanics \& Materials, 2017 (853): $168-172$.

[9] LH Luo, YH Huang, FZ Xuan. Pitting Corrosion and Stress Corrosion Cracking around Heat Affected Zone in Welded Joint of CrNiMoV Rotor Steel in Chloridized High Temperature Water [J], Procedia Engineering, 2015, 130 :1190-1198. 
[10] D Du, K Chen, H Lu, L Zhang, X Shi. Effects of chloride and oxygen on stress corrosion cracking of cold worked 316/316L austenitic stainless steel in high temperature water $[\mathrm{J}]$, Corrosion Science, 2016 (110): 134-142.

[11] J Torkkeli, T Saukkonen, H Hänninen. Effect of MnS inclusion dissolution on carbon steel stress corrosion cracking in fuel-grade ethanol [J], Corrosion Science, 2015 (96):14-22.

[12] Z Li, T Xiao, Q Pan, J Cheng, S Zhao. Corrosion behaviour and mechanism of basalt fibres in acidic and alkaline environments [J], Corrosion Science, 2016(110):15-22.

[13] R. N. Parkins, Metal Environmental Reactions, vol. 1, Newness Butterworths, 1976.

[14] Q Yu, CF Dong, JX Liang, ZB Liu, K Xiao. Stress corrosion cracking behavior of PH13-8Mo stainless steel in Cl-solutions [J], Journal of Iron \& Steel Research International, 2017, 24 (3): 282-289.

[15] Zhenyu Chen, Lingjie Li, Guoan Zhang, Yubing Qiu, Xingpeng Guo. Inhibition effect of propargyl alcohol on the stress corrosion cracking of super $13 \mathrm{Cr}$ steel in a completion fluid [J], Corrosion Science, 2013 (69): 205-210.

[16] C. S. O’Dell, B.F. Brown, Control of Stress Corrosion
Cracking by Inhibitors, Chemistry Department, American University, Washington, DC, 1978.

[17] L Niu, CN Cao, HC Lin, GL Song. Inhibitive effect of benzotriazole on the stress corrosion cracking of 18cr-9ni-ti stainless steel in acidic chloride solution [J], Corrosion Science, 1998, 40 (7) :1109-1117.

[18] QL Sun, LD Shi, ZR Liu. Effect on New Corrosion Inhibitor to Stress Corrosion Cracking of Prestressed Steel Wire in Simulated Concrete Pore Solution [J], Applied Mechanics \& Materials, 2014, 556-562: 667-670.

[19] N. Cansever, A. F. Caku, M. Urgen, Inhibition of stress corrosion cracking of AISI 304 stainless steel by molybdate ions at elevated temperatures under salt crust. Corrosion Science 41 (1999)1289-1303.

[20] Isao Sekine, Tetsuya Shimode, Makoto Yuasa, Corrosion Inhibition of Structural Steels in $\mathrm{CO}_{2}$ Absorption Process by Organic Inhibitor Composed of 8-Aminothiophenol, (1-Hydrox-yethylidene) bis (phosphonic acid), and Diethanolamine, Ind. Eng. Chem. Res. 1992, 31, 434-439.

[21] Corrosion of Metals and Alloys-Stress Corrosion Testing -part 2: Preparetion and use of Bent-Beam Specimens [S]. INT ERNATIONAL STANDARD. IS07539: 1989(E). 